\title{
Utilization of Lignocellulosic Wastes as a Carbon Source for the Production of Bacterial Cellulases under Solid State Fermentation
}

\author{
T. L. Tengku Norsalwani and N. A. Nik Norulaini
}

\begin{abstract}
Palm kernel cake (PKC) and vegetable wastes were used as a fermentation substrate for the evaluation of cellulase activity secreted by Bacillus sp. In the current work, PKC and vegetable wastes were used as substrates in order to reduce the cost of cellulase production. The aim of this study was to determine the cellulase activity by Bacillus sp. on lignocellulosic materials mainly on different sizes of PKC and vegetable wastes. Besides that, $\mathrm{pH}$, temperature, and inocula concentrations will also being tested for the optimum reaction of Bacillus sp. on the substrates. The PKC that were used can be divided into two types which are raw PKC and defatted PKC that had undergone Soxhlet oil removal. The results shown raw PKC, defatted PKC and vegetable wastes substrates have highest cellulase activity at $2.65 \mathrm{FPU} / \mathrm{ml}, 7.73$ FPU/ml and $85.48 \mathrm{FPU} / \mathrm{ml}$ respectively. The optimum $\mathrm{pH}$ and incubation temperature for cellulase activity of Bacillus sp. was pH 4 and $50^{\circ} \mathrm{C}$ respectively. Bacillus concentrations of $2 \times 105$ cells $/ \mathrm{ml}$ and $2 \times 106$ cells $/ \mathrm{ml}$, inoculated on PKCs and vegetable wastes produced the highest bacterial cellulases respectively. PKC with the particle size of $500 \mu m$ was the most effective in producing higher cellulase activity likewise for larger particle size, of $1 \mathrm{~mm}$ for vegetable wastes. From this study, Bacillus sp. holds the potential of converting lignocellulosic materials into products of commercial and industrial values such as glucose and other biofuels.
\end{abstract}

Index Terms-Biofield, cellulase activity, palm kernel cake, vegetable wastes, solid state fermentation.

\section{INTRODUCTION}

Commercial cellulases are mostly generated by fungi and there have been a plenty work conducted on this. Conversely, there are limited studies on cellulase production from bacteria [1]-[4] Cellulase has been widely used in the industries mainly in textile or pulp and paper industry. In most industries, cellulase contribute to the almost half of the total production costs. The application of biomass lignocelluloses in cellulase production has received attention nowadays as an alternative for the cellulase productions in exchange to the usage of purified cellulosic substrates such as Avicel and Solka Floc or soluble inducers such as lactose and carbomethyl cellulose [5]. Several cellulase production using lignocelluloses as a substrate such as banana fruit stalk, sugarcane bagasse, wheat straw, oil palm empty fruit bunch (OPEFB) and many more [6]-[9] In this study, we focus on the effects of incubation temperature, $\mathrm{pH}$, substrates particle size and inocula

Manuscript received January 30, 2012; revised March 7, 2012.

T. L. Tengku Norsalwani is with School of Distance Educations, Universiti Sains Malaysia (USM), 11800 Minden, Penang, Malaysia (email: tengku_norsalwani@yahoo.com).

N. A. Nik Norulaini is with the Division of Biological Sciences, School of Distance Educations, Universiti Sains Malaysia (USM), 11800 Minden, Penang, Malaysia (e-mail: norulain@usm.my). concentrations on cellulase production form Bacillus sp. using raw and defatted palm kernel cake and vegetable wastes as the carbon sources.

\section{MATERIALS AND METHOD}

\section{A. Production of Bacillus sp.}

The microbes (Bacillus sp.) from isolate B1 are grown on slant nutrient agar for 24 hours. In the first seeding process, the Bacillus sp. was inoculated onto the nutrient broth media consisted of $1.3 \%$ nutrient broth. The cultures were incubated for 5 days at room temperature, and $\mathrm{pH}$ was set to be between 5.0 to 7.5. The second seeding process was carried out by using the non-conventional process (involving aeration). A working stock was prepared comprising of $1.5 \%(\mathrm{w} / \mathrm{v})$ glucose, $0.15 \%(\mathrm{w} / \mathrm{v})$ ammonium sulfate, $0.04 \%(\mathrm{w} / \mathrm{v})$ potassium phosphate, $0.05 \%(\mathrm{w} / \mathrm{v})$ yeast extract, $0.1 \%(\mathrm{v} / \mathrm{v})$ Bacillus while the remaining purified water. The second seeding process undergoes a fermentation process that was completed in 16 to 22 hours. The working stock was adjusted to $\mathrm{pH}$ range of 5.0 to 7.5 using $1 \mathrm{~N} \mathrm{NaOH}$ according to the method outlined by Choi and Reynard [10]. The Bacillus sp. cells concentration was determined using a haemocytometer.

\section{B. Sampling and Preparation of Substrates (Palm Kernel Cake and Vegetables Waste)}

Freshly produced PKC was obtained from a local palm kernel mill. The fresh samples were divided into two portions. A portion was immediately stored at $4^{\circ} \mathrm{C}$ for later used and labeled as raw PKC. Another portion was defatted using soxhlet technique with hexane as solvent and extraction was carried out for 8 hour as done by Yan et al. [11]. The residual hexane was then removed and the defatted PKC was stored at $4^{\circ} \mathrm{C}$ until ready for use. Meanwhile, the vegetable waste was taken from the local market located at Bayan Baru, Pulau Pinang. The vegetable was dried inside the oven at $60^{\circ} \mathrm{C}$ for 24 hours. Both the PKC and the dried vegetables were grinded and the substrates were screened in a sieve shaker to obtain three mesh sizes (1) $250 \mu \mathrm{m}$, (2) $500 \mu \mathrm{m}$ and (3) $1 \mathrm{~mm}$.

\section{Solid State Fermentation}

Solid state fermentation of Bacillus sp. was performed with five grams ground raw PKC as the solid substrate with the addition of two $\mathrm{ml}$ of Mandels medium [12]. The Mandel's medium was prepared with the following composition (g/l): (1) urea, 0.3 ; (2) peptone, 0.75 ; (3) yeast extract, 0.25 ; (4) $\left(\mathrm{NH}_{4}\right)_{2} \mathrm{SO}_{4}, 1.4$; (5) $\mathrm{KH}_{2} \mathrm{PO}_{4}, 2.0$; (6) $\mathrm{CaCl}_{2}, 0.3$; (7) $\mathrm{MgSO}_{4} .7 \mathrm{H}_{2} \mathrm{O}, 0.3$, and trace elements (mg/l): (1) $\mathrm{FeSO}_{4} .7 \mathrm{H}_{2} \mathrm{O}, 5$; (2) $\mathrm{MnSO}_{4}$. $4 \mathrm{H}_{2} \mathrm{O}, 1.6$; (3) $\mathrm{ZnSO}_{4} .7 \mathrm{H}_{2} \mathrm{O}$, 1.4, and (4) $\mathrm{CoCl}_{2} \cdot 6 \mathrm{H}_{2} \mathrm{O}, 20.0$. The medium and the trace 
elements were autoclaved separately at $1.03 \times 10^{-5} \mathrm{~Pa}$, $121^{\circ} \mathrm{C}$ for $15 \mathrm{~min}$ and cooled to room temperature before one $\mathrm{ml}$ of sterilized trace elements was added and inoculated with different concentrations of Bacillus sp.: $2 \times 10^{8}, 2 \times 10^{7}, 2 \times 10^{6}$, and $2 \times 10^{5}$ cells $/ \mathrm{ml}$. The PKC and the inocula are mixed thoroughly and undergo $\mathrm{pH}$ adjustment to 6.5. Known volumes of sterile distilled water was added just enough to keep the PKC moist. The entire samples and controls were incubated for five days at ambient temperature. Controls were prepared the same as the other samples except without inoculation with Bacillus sp. The entire samples and controls were incubated for five days at $37^{\circ} \mathrm{C}$. Then, the test was repeated by using vegetable waste as substrates.

\section{Enzyme Extraction}

A $20 \mathrm{ml}$ distilled water was added to the five grams of fermented PKC (which had undergone the solid state fermentation earlier) and was swirl until homogenous. All the flasks were vigorously shaken on the rotary shaker at $200 \mathrm{rpm}$ for $30 \mathrm{mins}$. The solid biomass was separated from the suspension by filtration through Whatman No.1 filter papers. The supernatant was used as the source of crude enzyme preparation. Similar procedure was used to examine the effect of different treated raw and defatted PKCs and also the vegetable waste.

\section{E. Measurement of Enzyme Activity}

Measurement of enzyme activity was carried out based on the method of filter paper assay for saccharifying cellulose (FPU Assay) as outlined by Ghose [13]. One $\mathrm{ml}$ of $0.05 \mathrm{M}$ citrate buffer ( $\mathrm{pH} ; 3.0,4.0,5.0,5.5,6.0$, and 7.0.) was added to the test tube containing one Whatman No.1 filter paper strip $(1 \mathrm{~cm} \times 6 \mathrm{~cm})$. After that, $0.5 \mathrm{ml}$ of sample solution (supernatant) was added to the citrate buffer solution. The resulting solution was mixed thoroughly and then it was transferred to a water-bath maintained at 30,40 , and $50^{\circ} \mathrm{C}$. After 60 minutes (reaction step) the test tubes were removed from the water bath, and $3 \mathrm{ml}$ of DNS solution was added and mixed thoroughly to stop the enzymatic reaction. Tubes were covered and placed in a boiling water bath for $5 \mathrm{~min}$. All the tubes were cooled to room temperature with a cooling water bath. The absorbance was determined at 540 $\mathrm{nm}$ against water blank. The reducing sugar was estimated by plotting the absorbance to the glucose standard curve. Enzyme activity was expressed as FPU/ml (Amount of reducing sugar released per $\mathrm{ml}$ of filtrate per hour).

\section{F. Statistical Analysis}

The data in this experiment were analysed using Analysis of Variance (ANOVA) from Minitab 15 with 95\% of confidence interval.

\section{RESULTS}

\section{A. Effect of Incubation $p H$ on Cellulase Activity by Bacillus sp.}

The $\mathrm{pH}$ is an essential factor in determining the cell growth and enzyme production. The initial $\mathrm{pH}$ of the medium used varied between $\mathrm{pH} 3.0$ to 7.0 (Fig. 1). As shown in Table I, cellulase activity was found best in the medium with an initial $\mathrm{pH}$ of 4.0 with the maximum cellulase activity of $0.68 \mathrm{FPU} / \mathrm{ml}$. $\mathrm{pH}$ that is lower or higher than $\mathrm{pH} 4.0$ both reduced the cellulase production, exceptional for $\mathrm{pH}$ 7.0.

TABLE I: EFFECT OF INCUBATION PH OF MEDIUM ON CELLULASE PRODUCTION

\begin{tabular}{lc}
\hline \hline $\mathrm{pH}$ & Enzyme Activity, FPU/ml \\
\hline 3 & 0.63 \\
4 & 0.68 \\
5 & 0.66 \\
6 & 0.57 \\
7 & 0.62 \\
\hline
\end{tabular}

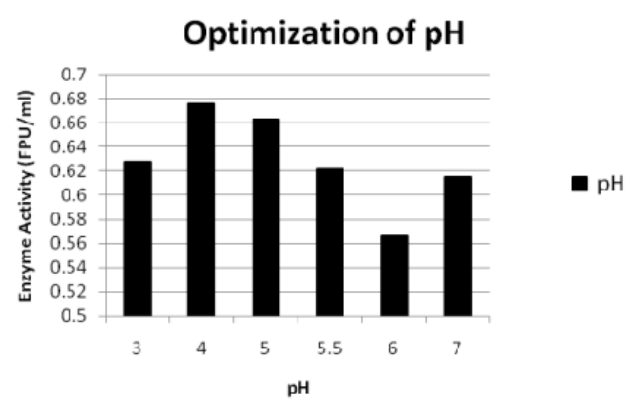

Fig 1 . The effect of the incubation $\mathrm{pH}$ on cellulase activity by Bacillus $\mathrm{sp}$. incubated for 5 days at room temperature $\left(30^{\circ} \mathrm{C} \pm 2\right)$.

\section{B. Effect of Incubation Temperature to the Cellulase Activity of Bacillus sp.}

The effects of incubation temperature on the cellulolytic activity were examined. The temperature range studies were $40-60^{\circ} \mathrm{C}$ (Fig. 2). As shown in Table II, $50^{\circ} \mathrm{C}$ proved to be the best temperature for the enzyme synthesis in the present study. The results revealed that Bacillus sp. grew significantly at the temperature of $50^{\circ} \mathrm{C}$ with the maximum cellulase activity of about $0.77 \mathrm{FPU} / \mathrm{ml}$ respectively. However, the production of enzymatic activity was found to decrease as the temperature increased. At the temperature below $50^{\circ} \mathrm{C}$, the production of cellulase activity was low.

TABLE II: EFFECT OF INCUBATION TEMPERATURE ON CELLULASE PRODUCTION BY BACILLUS SP.

\begin{tabular}{cc}
\hline \hline Temperature, ${ }^{\circ} \mathrm{C}$ & Enzyme Activity, FPU/ml \\
\hline 40 & 0.64 \\
50 & 0.77 \\
60 & 0.57 \\
\hline
\end{tabular}

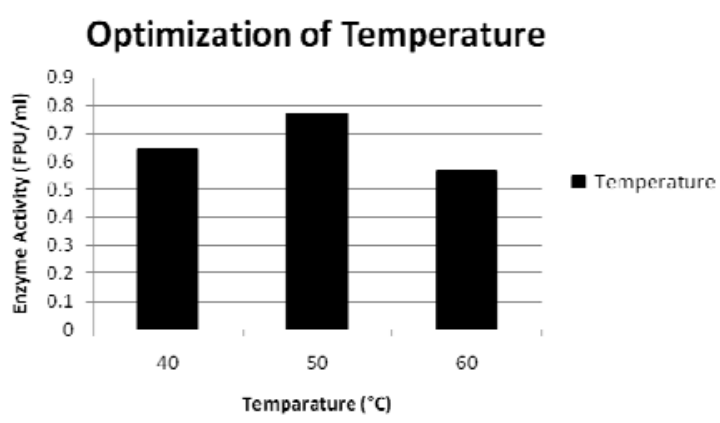

Fig 2. Effect of Incubation temperature on cellulase activity by Bacillus sp. incubated at different temperature. 


\section{Effect Of Inocula Concentrations On Cellulase Activity By Bacillus sp.}

The effect of the inocula size based on the spore count was studied. The inocula concentrations were varied from $2 \mathrm{x}$ $10^{8}, 2 \times 10^{7}, 2 \times 10^{6}$, and $2 \times 10^{5}$ cells $/ \mathrm{ml}$ (Table III). As shown in Fig. 3 and 5, when the inocula concentration was higher than $2 \times 10^{5}$ cells $/ \mathrm{ml}$, the enzyme activity is obviously low when tested on raw and defatted PKCs. Slight variations in the cellulase activity were observed when inoculated with concentrations ranging from $2 \times 10^{8}$ to $2 \times 10^{6}$ cells $/ \mathrm{ml}$,. Maximum cellulase activity was achieved in raw and defatted PKCs when inoculated with $2 \times 10^{5}$ cells $/ \mathrm{ml}$. Conversely, vegetable wastes gave the greatest cellulase activity when inoculated with $2 \times 10^{6}$ cells/ml (Fig. 7). Bacillus sp. as an inocula can yield maximum cellulase activity of $85.48 \mathrm{FPU} / \mathrm{ml}$ on vegetable wastes as a substrate.

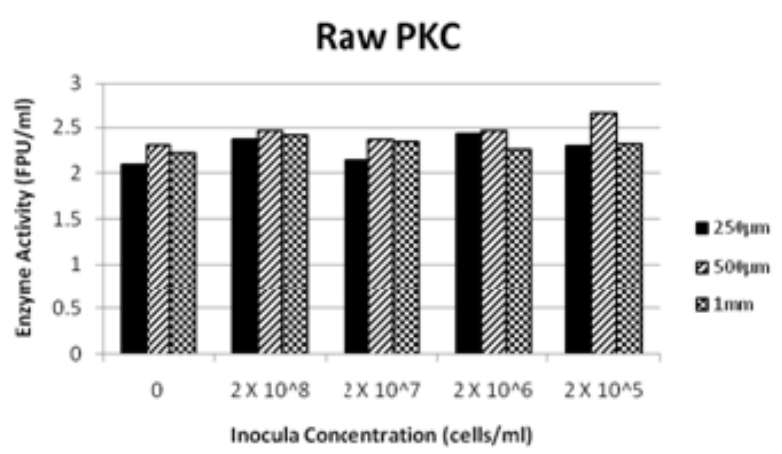

Fig 3. Cellulase activity by Bacillus sp. measured on different particle size of Raw PKC using different Inocula Concentration

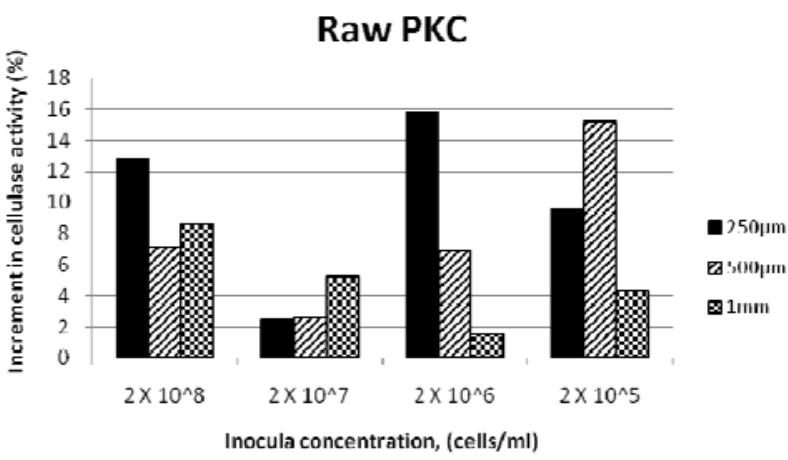

Fig 4. Percentage increment of cellulase activity by Bacillus sp. measured on different particle size of raw PKC using different inocula concentration

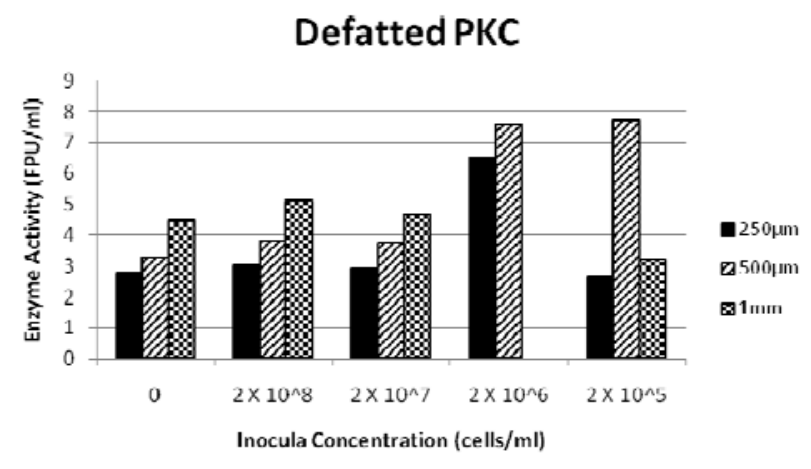

$\overline{\text { Fig 5. Cellulase activity by Bacillus sp. measured on different particle size }}$ of defatted PKC using different inocula concentration

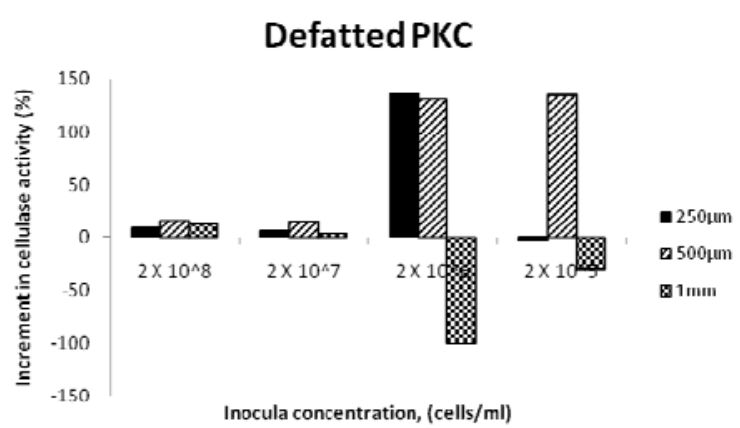

Fig 6. Percentage increment of cellulase activity by Bacillus sp. measured on different particle size of defatted PKC using different inocula concentration

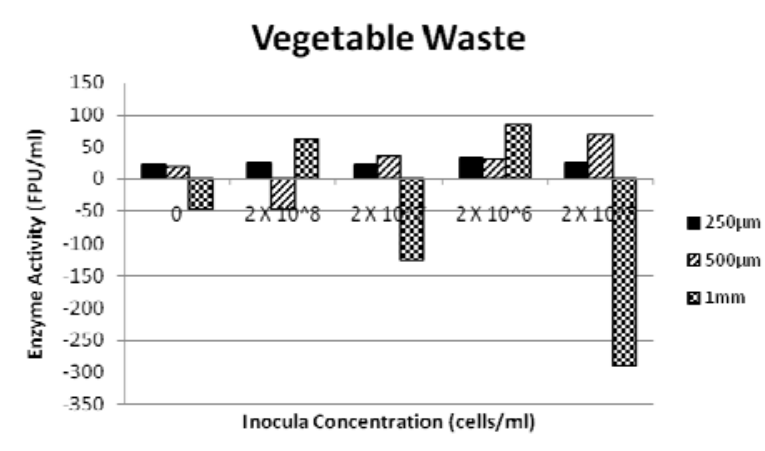

Fig 7. Cellulase activity by Bacillus sp. measured on different particle size of vegetable wastes using different inocula concentration.

TABLE III: EFFECT OF INOCULA CONCENTRATIONS AND PARTICLE SIZES ON CELLULASE PRODUCTION MEASURED ON DIFFERENT SUBSTRATES

\begin{tabular}{|c|c|c|c|c|}
\hline & & \multicolumn{3}{|c|}{ Enzyme Activity (FPU/ml) } \\
\hline $\begin{array}{l}\text { Particle } \\
\text { Size }\end{array}$ & $\begin{array}{c}\text { Inocula concentration } \\
(\text { cells } / \mathrm{ml})\end{array}$ & $\begin{array}{l}\text { Raw } \\
\text { PKC }\end{array}$ & $\begin{array}{l}\text { Defatted } \\
\text { PKC }\end{array}$ & $\begin{array}{l}\text { Vegetable } \\
\text { Wastes }\end{array}$ \\
\hline \multirow{5}{*}{$250 \mu \mathrm{m}$} & 0 & 2.09 & 2.76 & 22.44 \\
\hline & $2 \times 10^{8}$ & 2.36 & 3.01 & 25.68 \\
\hline & $2 \times 10^{7}$ & 2.14 & 2.91 & 21.25 \\
\hline & $2 \times 10^{6}$ & 2.42 & 6.52 & 33.57 \\
\hline & $2 \times 10^{5}$ & 2.29 & 2.68 & 24.88 \\
\hline \multirow{5}{*}{$500 \mu \mathrm{m}$} & 0 & 2.3 & 3.28 & 20.28 \\
\hline & $2 \times 10^{8}$ & 2.46 & 3.81 & -46.84 \\
\hline & $2 \times 10^{7}$ & 2.36 & 3.77 & 35.55 \\
\hline & $2 \times 10^{6}$ & 2.46 & 7.6 & 31.58 \\
\hline & $2 \times 10^{5}$ & 2.65 & 7.73 & 68.42 \\
\hline \multirow{5}{*}{$1 \mathrm{~mm}$} & 0 & 2.22 & 4.51 & -46.84 \\
\hline & $2 \times 10^{8}$ & 2.41 & 5.12 & 62.27 \\
\hline & $2 \times 10^{7}$ & 2.34 & 4.69 & -124.23 \\
\hline & $2 \times 10^{6}$ & 2.26 & 0.0 & 85.48 \\
\hline & $2 \times 10^{5}$ & 2.32 & 3.20 & -287.93 \\
\hline
\end{tabular}

D. Effect of Particle Sizes to the Cellulase Activity of Bacillus sp.

In this experiment, the particle sizes of substrates used were $250 \mu \mathrm{m}, 500 \mu \mathrm{m}$, and $1 \mathrm{~mm}$. Fig. 7 , shows the enzyme activity was higher with $1 \mathrm{~mm}$ particle size of vegetable wastes was used compared to $250 \mu \mathrm{m}$ and $500 \mu \mathrm{m}$ with the maximum yield of $85.48 \mathrm{FPU} / \mathrm{ml}$ cellulase activity. Of the various particle sizes examined, $500 \mu \mathrm{m}$ of defatted PKC and raw PKC (refer to Fig.3 and Fig.5) yield higher 
cellulase activity at $7.73 \mathrm{FPU} / \mathrm{ml}$ and $2.65 \mathrm{FPU} / \mathrm{ml}$ correspondingly.

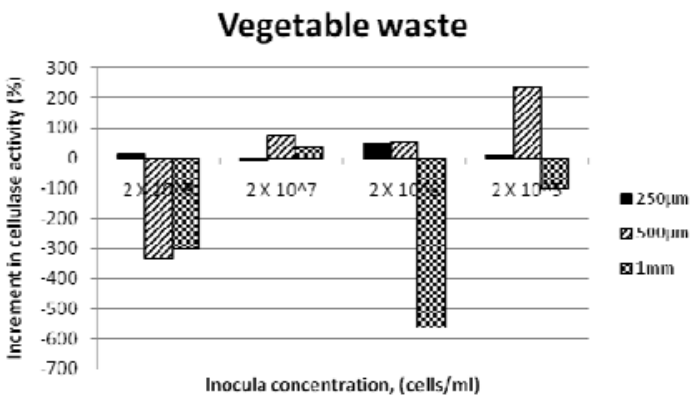

Fig 8. Percentage increment of cellulase activity by Bacillus sp. measured on different particle size of vegetable wastes using different inocula concentration.

Based on the statistical analysis, analysis of variance (ANOVA) using Minitab 15, the types and particle size of the substrates does not affect the enzymatic activity of Bacillus sp. significantly since its p value is more than 0.05 when tested with 95\% confidence level. Whereas, an inocula concentration shows significant result with $\mathrm{p}<0.05$.

\section{DISCUSSIONS}

\section{A. Effect of Incubation $\mathrm{pH}$ on the Cellulase Activity}

The $\mathrm{pH}$ growth range and $\mathrm{pH}$ growth optimum vary according to different microorganisms. Microorganisms often grow over wide range of $\mathrm{pH}$. Yet, extreme $\mathrm{pH}$ can damage microorganisms by distracting the plasma membrane as well as inhibiting the enzymatic activity and membrane transport proteins [14]. The influence of $\mathrm{pH}$ on in-house Bacillus sp. is shown in Fig. 1. As the $\mathrm{pH}$ of the medium increase, the cellulase activity generated by the Bacillus sp. also increased until pH 4.0. Further increase beyond $\mathrm{pH} 4.0$ resulted in lower cellulase activity achieved. Suitable $\mathrm{pH}$ is required for the enzyme to maintain the three dimensional shape of the active site. Changes in the $\mathrm{pH}$ might alter the ionic bonding of enzyme that contributed to the functional shape of the enzyme [15].

\section{B. Effect of Incubation Temperature on the Cellulase Activity}

Temperature sensitivity is one of the most important factors affecting the growth of microorganisms [14]. In this experiment, we aim to seek the optimal temperature cellulase activity. The results revealed that the cellulase activity tend to increase with temperature reaching optimum at $50^{\circ} \mathrm{C}$ (Fig.2). Further increase in temperature to $60{ }^{\circ} \mathrm{C}$ reduced the cellulase activity even much lower as compared with low temperature reaction. Extreme temperature reaction can lead to the modification of the active site enzyme and reduced available sites for the reaction process.

\section{Effect of Particle Sizes on the Cellulase Production}

The cellulase activity of Bacillus sp. was at its highest when the test was done on $500 \mu \mathrm{m}$ PKCs. Meanwhile, vegetable wastes sized $1 \mathrm{~mm}$, could produce more cellulase activity compare to other particle sizes vis $250 \mu \mathrm{m}$ and $500 \mu \mathrm{m}$. The disadvantages of the smaller particle sizes is that its low porosity characteristic will resulted in lack of inter-particle space. This will resulted in difficulty in bacterial respiration and will end up yielding low enzymatic activity [16]. Fan et al. [17] suggested that the increase in cellulase production did not solely depend on the amount of cellulose in the medium but may also depend on other factors such as pore size, surface area, cellulose crystallinity [18], substitution reactions with lignin-carbonium ion and depolymerization of lignin [19]. Ray et al. [20] obtained higher cellulase production from smaller OPEFB fibre size ( $2 \mathrm{~mm}$ rather than $10 \mathrm{~mm}$ ) and it may be attributable to the decrease in particle size caused by the impact energy transfer of hammer milling. Reducing lignocellulose length greatly increased the surface area and reduced the diffusion path of reactants for enzymatic hydrolysis.

\section{Effect of Inocula Sizes on the Cellulase Production}

Inocula size plays an important role in achieving maximum bacterial growth and enzyme production by Bacillus sp. in a solid state fermentation. In this experiment, the cellulase activity increased when the low inocula sizes were used. The cellulase activity started to increase until $2 \mathrm{x}$ $10^{6}$ cells $/ \mathrm{ml}$ of inocula were used before it gradually dropped when higher concentration was used. Reference [21], [22] elucidated that cellulase production by Bacillus sp. increased gradually up to $3 \%$ inoculums size but decreased thereafter even with the increment of the inocula sizes. Similar findings was reported by Sarkar et al. [23] whom achieved the maximum cellulase activity at $2 \%$ inocula sizes before it gradually decreased with the increase in inocula sizes.

Reference [24]-[26] reported that the fungal growth was increased as the inocula size increased until it achieved the optimal inocula size then, the growth decreased sharply by the increase of the inocula size over the optimal one. It was proven that after the optimal growth, an increase in inocula size will lead to the low enzyme productivity due to the fast growing rate of the microorganism that will increase the competition for the nutrient and space. This at the same time will affect the stationary phase length which in the end affects the enzyme productivity.

\section{E. Comparison of Cellulase Production Using Different Carbon Sources}

A comparison of cellulase production using PKCs and vegetable wastes is given in Table 6. As can be seen, vegetable wastes are better substrates for growth and cellulase production compared to PKCs. The maximum cellulase activity obtained from the fermentation of Bacillus sp. on vegetable wastes shows increment of more than $100 \%$ cellulase activity compare to PKCs. It was about 12 times more than those obtained from fermentation of PKCs.

Overall, a differential effect of the carbon sources on cellulase production was observed, this finding is in agreement with [9], [27], who demonstrated that the production of cellulase is influenced by the carbon source used. High cost of substrates can be a limiting factor in enzyme production.

\section{CONCLUSIONS}

PKC and vegetable wastes were found to be suitable as substrates for cellulase production by Bacillus sp. in solid state fermentation, with substantial enhancement in growth and enzyme production. It was also an alternative to reduce 
the costs for enzyme productions. PKCs with particle size of $500 \mu \mathrm{m}$ produced maximum activity when inoculated with 2 x $10^{5}$ cells $/ \mathrm{ml}$ of Bacillus sp. while vegetable wastes sized $1 \mathrm{~mm}$ yield its maximum activity during an inoculation with $2 \times 10^{6}$ cells $/ \mathrm{ml}$ of Bacillus $\mathrm{sp}$.

\section{ACKNOWLEDGMENT}

Authors wish to express their gratitude to the other colleagues for their support of the research. Authors also wants to acknowledge Pro-Fil Company, Fleet Palms Sdn. Bhd and Universiti Sains Malaysia (USM) for funding the research and School of Industrial Technology, USM, for the research resources, equipment and facilities provided. Special thanks to Ms. Jannah Hasnan and Mrs. Shalima for the help during the experiment.

\section{REFERENCES}

[1] J. X. Heck, P. F. Hertz, and M. A. Z. Ayub, "Cellulase and xylanase production by isolated Amazon Bacillus strains using soybean industrial residue based solid-state cultivation," Braz. J. Microbiol., vol. 33, pp. 213-218, 2002.

[2] O. S. Kotchoni, O.O. Shonukan, and W. E. Gachomo, "Bacillus pumillus, BpCRI 6, a promising candidate for cellulase production under conditions of catabolite repression," Afr. J. Biotechnol., vol. 2, pp. 140-146, 2003.

[3] C. Krishna, "Production of bacterial cellulases by solid state bioprocessing of banana wastes," Bioresour. Technol., vol. 69, pp. 231-239, 1999.

[4] C. R. Sanchez, C. S. Peres, and H. R. Barbosa, "Growth and endoglucanase activity of Acetovibrio cellulolyticus grown in three cellulosic substrates," Rev. Microbiol., vol. 30, pp. 310-314, 1999.

[5] M.S. Umikalsom, "Optimization of cellulase production by Chaetomium globosum strain 414 using oil palm empty fruit bunch fibre as substrate," Ph.D. dissertation, University Putra Malaysia, Malaysia, 1997.

[6] H. Jorgensen, and L. Olsson, "Production of cellulase by Penicillium brasilianum IBT 20888-effect of substrate on hydrolytic performance," Enzyme Microb. Technol., vol. 38, pp. 381-390, 2006.

[7] A. L. Kansoh, S. A. Essam, and A. N. Zeinat, "Biodegradation and utilization of bagasse with Trichoderma reesie," Polym. Degrad. Stab., vol. 63, pp. 273-278, 1999.

[8] M. I. Rajoka, and K. A. Malik, "Cellulase production by Cellulomonas biazotea cultured in media containing different cellulosic substrates," Bioresour. Technol., vol. 59, pp. 21-27, 1997.

[9] M. A. O. Sattam, "Xylanase production by Phanerochaete Chrysosporium ME 446 (ATCC 34541) in a submerged culture system," Ph.D. dissertation, Universiti Sains Malaysia, Malaysia, April 2001.

[10] H. Y. Choi, and G. Reynard, "Production of fermented palm kernel cake (pkc)," USPTO Patent Application 20060292264.
[11] F. Y. Yan, D. Krishniah, M. Rajin, and A. Bono, "Cellulose extraction from palm kernel cake using liquid phase oxidation," Journal of Engineering Science and Technology, vol. 4, no. 1, pp. 5768, 2009.

[12] M. Mandels, R. Andreotti, and C. Roche, "Measurement of saccharifying cellulase," in Enzymatic Conversion of Cellulosic Materials Technology and Applications. John Wiley \& Sons, New York 1976, p. 21.

[13] T. K. Ghose, "Measurement of cellulase activities," Pure and Appl. Chem., vol. 59, Issue 2, pp. 257-268, 1987.

[14] M. L. Shuler and F. Kargi, Bioprocess engineering: basic concepts, 1st ed. New Jersey: Prentice Hall, 1992.

[15] Z. Xu, Q.H. Wang, Z.H. Jiang, X.X. Yang, and Y.Z. Ji, "Enzymatic hydrolysis of pretreated soybean straw," Biomass Bioenerg, vol. 31, pp. 162-167, 2007.

[16] M. S. Umikalsom, A. B. Ariff, H. S. Zulkifli, C. C. Tong, M. A. Hassan, and M. I. A. Karim, "The treatment of oil palm empty fruit bunch fibre for subsequent use as substrate for cellulase production by Chaetomium Globosum Kunze," Bioresource Technology, vol. 62, pp. 1-9, 1997.

[17] L. T. Fan, Y. H. Lee, and D. H. Baerdmore, "Mechanism of the enzymatic hydrolysis of cellulose; effects of major structural features of cellulose on enzymatic hydrolysis," Biotechnology and Bioengineering, vol. 22, pp. 177-199, 1980.

[18] T. K. Ghose, P. V. Panni-Selvam, and P. Ghose, "Catalytic solvent delignification of agricultural residues: organic catalyst," Biotechnology and bioengineering, vol. 25, pp. 2577-2590, 1983.

[19] J. C. Parajo, J. L Alonso, and V. Santos, "Delignification and swelling of Eucalpytus wood ahead of enzymatic hydrolysis of the cellulosic fraction," Process Biochemistry, vol. 30, pp. 537-545, 1995.

[20] A. K. Ray, A. Bairagi, K. S. Ghosh, and S. K. Sen, "Optimization of fermentation conditions for cellulase production by Bacillus subtilis CY5 and Bacillus circulans TP3 isolated from fish gut," Actachthyologica ET Piscatoria, vol. 37, no. 1, pp. 47-53, 2007.

[21] T. Shankar, and Isaiarasu, "Production by Bacillus pumilus EWBCM1 under varying cultural conditions," Middle-East Journal of Scientific Research, vol. 8, no. 1, pp. 40-45, 2011.

[22] R. Sen, and T. Swaminathan, "Application of response-surface methodology to evaluate the optimum environmental conditions for the enhances production of surfactin," Applied Microbiology and Biotechnology, vol. 47, pp. 358-363, 1997.

[23] S. Sarkar, B. Sreekanth, S. Kant, R. Banerjee, and B. C. Bhattacharyya, "Production and optimization of microbial lipase," Bioprocess Engineering. vol. 19, pp. 29-32, 1998.

[24] C. Sekar, and K. Balaraman, "Optimization studies on the production of cyclosporine A by solid state fermentation," Bioprocess Engineering. vol.18, pp. 293-296, 1998.

[25] R. Doppelbauer, H. Esterbauer, W. Steiner, R. M. Lafferty, and H. Steinmuller, "The use of lignocellulosic wastes for production of cellulase by Trichoderma reesei," Applied microbiology and biotechnology, vol. 26, pp. 485-494, 1987.

[26] A. Hidayah, A. H. Mohd, M. S. Umikalsom, A. Norhafizah, M. G. Farinazleen, and S. Yoshihito, "Production of bacterial endoglucanase from pretreated oil palm empty fruit bunch by Bacillus pumilus EB3," The society for biotechnology, Japan. Journal of bioscience and bioengineering, vol. 106, no.3, pp. 231-236, 2008.

[27] G. Zacchi, K. Skoong, and B. Hahn-Hagerdal, "Economic evaluation of enzymatic hydrolysis of phenol-pretreated wheat straw," Biotechnol. Bioeng., vol. 32, pp. 460-468, 1988. 